\title{
US and UK to block limits
}

\section{London \& Washington}

A Row is likely to blow up at an international conference on sustainable economic development in Bergen, Norway, over the wording of a ministerial declaration to be produced on 16 May. Several nations, led by the United States, object to Norwegian proposals to set definite targets for environmental improvements, notably a commitment to stabilize carbon dioxide emissions at today's levels by the year 2000 .

The Bergen conference is organized by the United Nations Economic Commission for Europe (UNECE), and is one of four regional conferences following on from the 1987 report of the United Nations World Commission on Environment and Development, chaired by Gro Harlem Bruntland, then prime minister of Norway. The four regional conferences will assemble advice in preparation for a global conference on the environment and

The environmentalist pressure group Friends of the Earth released a leaked telex, dated 24 April, which they say was sent from the US government to a number of its embassies. The telex says that US officials expect Britain, Canada and the Soviet Union to agree with the US position that no specific targets for carbon dioxide emissions should be adopted at least until the release, later this summer, of reports from the three working parties of the Intergovernmental Panel on Climate Change. These reports will be debated at a World Climate Conference in the autumn. The leaked telex advises US officials abroad that West Germany, the Netherdevelopment, planned for 1992.

lands, Belgium, France, Denmark and Sweden will support the Norwegian advocacy of rigid targets.

Although the content of the telex is unsurprising, as it repeats publicly stated policy, its release is likely to add to enviromentalists' belief that the US and UK governments are not giving environmental issues urgent consideration. Misgivings have also arisen over these countries' choice of delegates for the conference. In both cases, top-level cabinet ministers have been replaced by junior officials. Britain is represented by David Trippier, deputy to Secretary of State for the Environment Chris Patten, who begged off on the grounds of domestic work pressures. And although US Environmental Protection Agency administrator William Reilly had been invited to the conference, the White House decided instead to send a small team headed by John Knauss, a scientist from the National Oceanic and Atmospheric Administration.

In the United States, where leaked government documents and internal policy disputes are becoming a familiar feature of environmental negotiations, environmentalists are pointing to the latest controversy as a further indication that the Bush adminstration has underestimated the ability of the environment to dominate international politics.

"Until the administration realizes that the environment is a powerful issue, they'll have to be dragged kicking and screaming into more action." says Michael Oppenheimer of the Environmental Defense Fund. Peter Aldhous \& G. Christopher Anderson

\section{US says no to international ozone plan}

Washington

ENVIRONMENTAL ministers at a United Nations conference in Geneva sharply criticized the United States last week for opposing a plan to help developing countries to phase out ozone-destroying chlorofluorocarbons (CFCs) and use less damaging but more expensive alternatives. Of the $\mathbf{5 0}$ or so countries represented, only the United States rejected the plan, which would set up a $\$ 100$ million fund to help developing countries switch to CFC substitutes as they become available. US officials said that they believe the World Bank is the best source for such a fund.

Delegates were meeting in Geneva to prepare for a conference in London next month at which the 54 nations that have ratified the Montreal Protocol on CFC reduction will discuss strengthening the treaty. At present, the protocol calls for a 50 per cent worldwide reduction in CFCs by the year 2000 , but, with a number of
While you're up there. . .

\section{Washington}

WHEN two adventurers and a Soviet cosmonaut embark on a round-the-world balloon voyage near the end of the year, they will be carrying instruments that may provide unique data on the ozone layer and atmospheric turbulence, officials said at a press conference held last week to announce the project. As part of an agreement worked out with the US National Aeronautics and Space Administration (NASA), the three-man balloon will carry scientific instruments in exchange for navigation and communications assistance from the space agency.

Richard Branson, the British entrepreneur who founded Virgin Records and Virgin Atlantic Airways, is underwriting most of the project and will be the balloon's captain. Larry Newman, who gained the current balloon distance record with a trans-Pacific voyage in 1981, and Vladimir Dzhanibekov, a Soviet cosmonaut, will complete the crew.

If winds, weather and equipment cooperate, the balloon, known as Earthwinds, will be the first to circumnavigate the globe. It will be launched from a former dirigible hangar in Akron, Ohio, some time between November and February. With jetstream winds that can reach 200 m.p.h., project planners hope the trip will last less than three weeks.

NASA instruments on board the 24-foot gondola will include five accelerometers to measure changes in the balloon's velocity due to wind shear. Vortices in the jetstream can keep water vapour, particles and gases in suspension for long periods and are an important element in atmospheric chemistry. But few vortex observations have extended beyond relatively small geographic areas.

Earthwinds will try to follow the 40th parallel all around the world, and should provide a complete global strip of atmospheric turbulence data, NASA scientists say. Other instruments will include two anemometers to measure wind shear beneath the balloon and radiosonde packages to measure temperature, pressure and humidity.

NASA scientists also hope to gain a new global perspective on the ozone layer with a radiometer that will measure the intensity of ultraviolet light shining on the balloon from above. Because the balloon, at an altitude of about 35,000 feet, will be at the bottom of the stratosphere, the amount of ultraviolet light received should measure the amount of stratospheric ozone above the balloon's path.

Beyond the direct scientific value of such information, NASA hopes to use the data to calibrate its orbiting Total Ozone Mapping Spectrometer, which has been aboard the Nimbus 7 satellite since 1977.

G. Christopher Anderson 